\title{
Severe Yellowing Outbreaks in Tomato in Spain Associated with Infections of Tomato chlorosis virus
}

\author{
J. Navas-Castillo, R. Camero, M. Bueno, and E. Moriones, Estación Experimental "La Mayora", Consejo Supe- \\ rior de Investigaciones Científicas (CSIC), 29750 Algarrobo-Costa, Málaga, Spain
}

\begin{abstract}
Navas-Castillo, J., Camero, R., Bueno, M., and Moriones, E. 2000. Severe yellowing outbreaks in tomato in Spain associated with infections of Tomato chlorosis virus. Plant Dis. 84:835-837.

Since 1997, yellowing disease outbreaks have occurred in tomato (Lycopersicon esculentum) crops in southern Spain. The outbreaks were associated with high populations of the whitefly Bemisia tabaci. Symptoms consisted mainly of interveinal yellowing that developed initially on lower leaves and then progressed to the upper part of the plant. Affected plants were less vigorous and yielded less due to reduced fruit growth and delayed ripening. During 1998 and 1999, the yellowing disease was widespread and occurred at high incidences in the Málaga province. The disease agent was readily transmissible from tomato to tomato by B. tabaci biotype Q. Samples from symptomatic tomato plants were analyzed and shown to be infected with Tomato chlorosis virus (ToCV) (genus Crinivirus, family Closteroviridae). This is the first report of ToCV epidemics in Europe.
\end{abstract}

Abnormal yellowing symptoms have been observed since 1997 in tomato (Lycopersicon esculentum Mill.) crops grown in the Málaga and Almería provinces of southern Spain. Symptomatic plants were not frequent in 1997 and symptoms were attributed by growers to physiological or nutritional disorders, although a random distribution of affected plants was observed in the fields. However, in 1998 and, especially, during 1999, severe outbreaks of the yellowing disease associated with high populations of the whitefly Bemisia tabaci Gen were observed in Málaga. In this same area, infections of tomatoes caused by Tomato yellow leaf curl virus (TYLCV)-Sar and TYLCVIs (genus Begomovirus, family Geminiviridae) are widespread $(7,8)$. Epidemics of TYLCV are also associated with $B$. tabaci infestations. However, the symptoms induced by TYLCV in tomato differed considerably from the yellowing disease reported in this article $(6,10)$. Plants affected by the yellowing disease exhibited symptoms that resembled those described in the United States for the infections caused by

Corresponding author: E. Moriones

E-mail: moriones@eelm.csic.es

This work was financed by project AGF98-0439 of the Comisión Interministerial de Ciencia y Tecnología, Spain. GenBank Accession numbers of sequences reported in this work are AF215817, AF215818, and AF233435.

Accepted for publication 25 April 2000.

Publication no. D-2000-0602-01R

(C) 2000 The American Phytopathological Society
Tomato infectious chlorosis virus (TICV) and Tomato chlorosis virus (ToCV). These are members of the genus Crinivirus in the family Closteroviridae $(4,14,15)$. The etiology of the yellowing disease of tomato was analyzed in this study.

\section{MATERIALS AND METHODS}

Field surveys. Leaf samples were collected from tomato plants in plastichouse crops grown in southern Spain exhibiting the abnormal yellowing disease. In all, 1 plant was sampled in Málaga in July 1997, 2 plants in Almería in July 1998, and 13 plants in Málaga in July and August 1999, the last from several tomato fields covering the majority of tomato-growing area of the Málaga province. The youngest symptomatic leaf was collected and maintained at $-70^{\circ} \mathrm{C}$ until analyzed. During autumn 1999, a survey was undertaken in the Málaga province to determine incidence of the yellowing disease in plastichouse tomato crops. Four sites, $15 \mathrm{~km}$ apart, representing the main tomato-growing area were surveyed. At each site, several randomly selected commercial tomato crops transplanted during June and July were inspected. For each field visited, the tomato cultivar was recorded and the incidence of the yellowing disease was expressed as the percentage of symptomatic plants over 200 to 300 plants evaluated.

Whitefly transmission. The youngest symptomatic leaf of a tomato plant exhibiting the yellowing disease was sampled in Málaga during 1999 and used as a source for insect transmission experiments. $B$. tabaci biotype Q (5) was used for transmission because it is the most widespread in southern Spain (J. L. Cenis, unpublished data). Adult individuals from nonviruliferous colonies were confined to symptomatic leaf for a 48-h acquisition access period using a clip-on cage. They were then caged in groups of 20 on the second leaf from the apex of each of seven healthy tomato (cv. Moneymaker) test plants at the four-leaf growth stage. Whiteflies were allowed to feed for a 48-h inoculation access period (IAP). After the IAP, test plants were sprayed with an insecticide and held in an insect-proof glasshouse until analyzed. Controls were two tomato plants exposed under the same conditions to whiteflies from nonviruliferous colonies.

RNA extraction and amplification by reverse transcription-polymerase chain reaction. Total RNA was extracted from tomato samples using methods described previously (2). Healthy tomato plants were used as negative controls. Oligonucleotide primers that can amplify both TICV and $\mathrm{ToCV}$ genomes were designed based on the nucleotide sequences of the HSP70 homolog genes reported for these viruses (GenBank Accession numbers U67449 and AF024630, respectively) with degeneracies at the nonidentical positions: primer MA59 (5'-TT(A/G)GA(T/G)TT(C/T)GGTACTA$\left.\mathrm{C}(\mathrm{A} / \mathrm{T}) \mathrm{TTCAG}-3^{\prime}\right)$ corresponding to nucleotides 19 to 41, and primer MA60 (5'AA(A/T)GTACC(T/G)CCACCAAA(A/G) TCGT-3'), complementary to nucleotides 605 to 585 (residue numbers referring to the sequence of the ToCV HSP70 homolog gene).

First-strand cDNA was synthesized using total RNA as a template. Total RNA extracted from $7 \mathrm{mg}$ of plant tissue and $150 \mathrm{ng}$ of primer MA60 was heated at $75^{\circ} \mathrm{C}$ for $5 \mathrm{~min}$, followed by chilling in ice. The RNA was reverse transcribed by incubation at $42^{\circ} \mathrm{C}$ for $1 \mathrm{~h}$ in a $20-\mu$ reaction containing $50 \mathrm{mM}$ Tris- $\mathrm{HCl} \mathrm{pH} 8.3,10$ $\mathrm{mM} \mathrm{KCl}, 5 \mathrm{mM} \mathrm{MgCl} 2,0.5 \%$ Tween-20, $10 \mathrm{mM}$ dithiothreitol, $1 \mathrm{mM}$ each of the four dNTPs, 10 units of RNasin ribonuclease inhibitor (Promega Corp., Madison, WI), and 50 units of Expand reverse transcriptase (Boehringer Mannheim, Mannheim, Germany). Polymerase chain reaction (PCR) amplification was performed with $5 \mu \mathrm{l}$ of the reverse transcription reaction mix in a $25-\mu$ l reaction mixture containing $10 \mathrm{mM}$ Tris- $\mathrm{HCl} \mathrm{pH} 8.3,1.5 \mathrm{mM}$ $\mathrm{MgCl}_{2}, 0.2 \mathrm{mM}$ each of the four dNTPs, 2.5 units of Taq DNA polymerase (Boehringer Mannheim), and $75 \mathrm{ng}$ each of the primers MA59 and MA60. After an 
initial denaturation step at $94^{\circ} \mathrm{C}$ for $1 \mathrm{~min}$, PCR was performed with 30 cycles, each at $94^{\circ} \mathrm{C}$ for $30 \mathrm{~s}, 58^{\circ} \mathrm{C}$ for $30 \mathrm{~s}$, and $72^{\circ} \mathrm{C}$ for $1 \mathrm{~min}$, followed by an extension step at $72^{\circ} \mathrm{C}$ for $5 \mathrm{~min}$. Reverse transcription (RT)-PCR products were separated by electrophoresis in 1\% agarose gels in TAE buffer (40 mM Tris-acetate, $1 \mathrm{mM}$ EDTA, $\mathrm{pH}$ 8.0) and detected by ethidium bromide staining. Aliquots of RT-PCR DNA products were digested with TaqI or AluI and analyzed by electrophoresis in $2 \%$ agarose gels in TAE buffer.

Nucleotide sequencing and sequence analysis. RT-PCR DNA products obtained from tomato field samples were directly sequenced. Nucleotide sequences were determined in both directions with an ABI PRISM DNA sequencer 377 (Perkin-Elmer, Foster City, CA), using the primer pair MA59/MA60. Translation to amino acid sequence, multiple alignments, and comparisons of the nucleotide and amino acid sequences were done using the programs Translator, PileUp, and Distances, respectively, from the Wisconsin GCG software package (3).

\section{RESULTS AND DISCUSSION}

Tomatoes for fresh market are widely grown along the Mediterranean coast of southern Spain. A novel disease was ob- served (beginning in 1997), consisting of irregular chlorotic areas that evolved to interveinal yellowing, beginning on lower leaves and gradually progressing to the upper part of the plant. A few weeks later, affected plants exhibited a generalized interveinal bright yellowing of leaves with dark green veins. Symptomatic plants were less vigorous, causing severe yield losses due to reduced fruit growth and delayed ripening. Symptomatic plants occurred at random in affected fields. This pattern seemed to exclude physiological or nutritional disorders as the cause of the disease. Symptoms strongly resembled those reported for TICV and ToCV infections in tomato $(14,15)$. A PCR DNA product of the expected size $(587 \mathrm{bp})$ based on the nucleotide sequences of TICV and ToCV isolates reported in the Unites States $(14,15)$ was obtained from the sample collected in Málaga in 1997, from one sample collected in Almería in 1998, and from all the samples collected in Málaga in 1999 (Fig. 1A). A second faint, slower-migrating amplification product was obtained from some of the field-collected samples (Fig. 1A, lane 5). A similar amplification product was obtained occasionally from the healthy tomato plants used as controls (Fig. 1A, lane 2 versus lane 3) and was associated with recognition of tomato constitu-

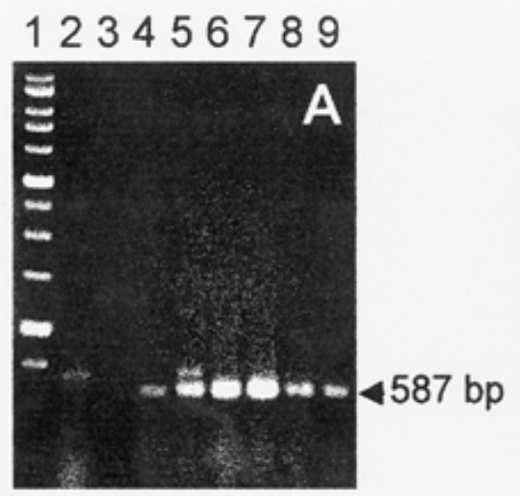

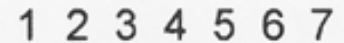

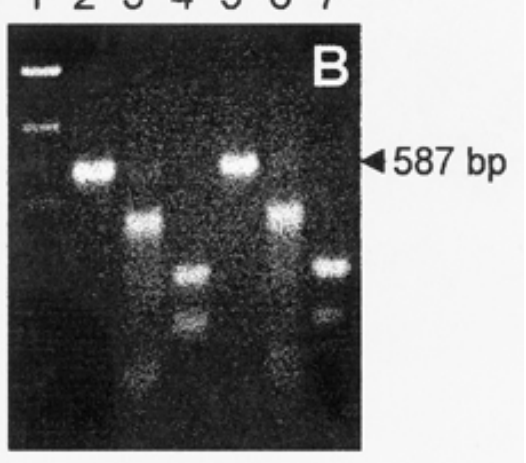

tive HSP70 homolog genes by the M59/M60 primer pair. A close relationship was found, therefore, between exhibition of yellowing symptoms in plants and the occurrence of a 587-bp DNA product in the RT-PCR analysis.

The yellowing disease epidemics occurred each year and correlated with the main spread of B. tabaci populations (late June to late October). B. tabaci transmission experiments were performed from symptomatic to healthy tomatoes, showing that six of the seven tomato test plants used for insect transmission developed yellowing symptoms similar to those observed in the field 60 days after the IAP. RT-PCR analysis of samples from these plants resulted in the amplification of a PCR DNA product with size similar to that amplified from the source plant (Fig. 1B, lane 5 versus lane 2). No PCR DNA product was obtained from trials on asymptomatic plants or from plants subjected to whiteflies fed on a healthy source tomato plant (data not shown). The identity of the PCR DNA fragments amplified from $B$. tabaci-inoculated plants and from the plant used as the virus source for transmission was studied by restriction digestion analysis using $A l u \mathrm{I}$ or $T a q \mathrm{I}$ restriction endonuclease. Identical restriction patterns were obtained in both cases (Fig. 1B, lanes 6 and 7 versus lanes 3 and 4), indicating that the agent associated with the yellowing disease in tomato was readily transmissible by $B$. tabaci, as was reported for ToCV (14) but not for TICV (4).

The PCR DNA products amplified from the sample collected in Málaga during 1997 , from one of the samples collected in Almería during 1998, and Málaga during 1999 (isolates AT1/97, AT3/98, and AT24/99, respectively) were selected for sequence analysis. The complete nucleotide sequences were obtained by direct sequencing of the PCR DNA products and deposited in the EMBL/GenBank Database (Accession numbers AF233435, AF215817, and AF215818, respectively). The nucleotide sequences obtained were $99 \%$ identical and showed $98 \%$ nucleotide sequence identity to the corresponding HSP70 homolog coding regions of the ToCV isolate reported in the United States (referred to as USA-ToCV; 14). These sequences were only $56 \%$ identical to the equivalent region of TICV (15). The deduced amino acid
Fig. 1. (A) Reverse transcription-polymerase chain reaction (RT-PCR) analysis performed on samples from tomato field plants exhibiting the yellowing disease collected in Málaga during 1997 (lane 4) and 1999 (lanes 6 to 9), Almería during 1998 (lane 5), and RT-PCR from healthy tomato plants (lanes 2 and 3). (B) Restriction endonuclease analysis of the PCR DNA products obtained from one tomato field sample (lanes 2 to 4 ) and from a sample of a tomato test plant resultant of the Bemisia tabaci transmission from that field sample (lanes 5 to 7): undigested (lanes 2 and 5), AluI-digested (lanes 3 and 6), and TaqI-digested (lanes 4 and 7). Lanes 1 in A and B: 1-kb ladder molecular size marker. The 587-bp PCR DNA fragments are indicated with arrowheads. Electrophoresis was performed in $1 \%$ (A) or $2 \%$ (B) agarose gel in Tris-acetate-EDTA buffer.

Table 1. Incidence of the yellowing disease in plastichouse tomato (Lycopersicon esculentum Mill.) crops at four sites representative of the major tomatogrowing area of the Málaga province (southern Spain) surveyed during 1999

\begin{tabular}{lccccccc}
\hline & & \multicolumn{7}{c}{ No. of fields with incidence level $(\mathbf{\%})^{\mathbf{a}}$} & \\
\cline { 3 - 7 } Site & No. of fields inspected & $<\mathbf{2 0}$ & $\mathbf{2 0 - 4 0}$ & $\mathbf{4 0 - 6 0}$ & $\mathbf{6 0 - 8 0}$ & $>\mathbf{8 0}$ & Cultivar \\
\hline Valle Niza & 3 & $\ldots$ & $\ldots$ & 1 & 2 & $\ldots$ & Brillante \\
Almayate & 2 & $\ldots$ & 1 & 1 & $\ldots$ & $\ldots$ & Brillante \\
Algarrobo & 9 & $\ldots$ & 4 & 3 & 1 & $\ldots$ & Brillante, Daniela, Alcudia \\
El Morche & 7 & 1 & 2 & 3 & $\ldots$ & Brillante, Daniela, Rambo \\
\hline
\end{tabular}

\footnotetext{
${ }^{\text {a }}$ Incidence of symptomatic plants exhibiting the yellowing disease of over 200 to 300 plants evaluated; ... indicates that no field with this incidence level
} was observed. 
sequences were 180 amino acids long and comprised amino acids 15 to 194 (numbers referring to the amino acid sequence deduced from the HSP70 homolog gene of the USA-ToCV). The amino acid sequences deduced for AT1/97 and AT3/98 were identical. The amino acid sequence deduced for AT24/99 differed in an N to S change at position 45 with respect to those of AT1/97, AT3/98, and USA-ToCV. An additional $\mathrm{T}$ to $\mathrm{M}$ change at position 91 was found in the amino acid sequences deduced for AT1/97, AT3/98, and AT24/99 with respect to that of the USA-ToCV. Therefore, samples AT1/97, AT3/98 and AT24/99 were infected with ToCV. In addition, restriction fragment analysis of the PCR DNA fragments amplified from the remaining unsequenced samples collected from Málaga during 1999 showed restriction patterns identical to those of AT1/97, AT3/98 and AT24/99 (data not shown), suggesting that those samples also were infected with ToCV.

A large-scale survey, conducted during 1999, showed that the yellowing disease was widespread in commercial fields visited at four sites covering the major tomato growing areas of the Málaga province (Table 1). Incidences of over $30 \%$ symptomatic plants in individual fields were frequent in all of the sites visited. Moreover, no evident differences were observed in the incidence of the yellowing symptoms among the different tomato cultivars grown in this region. Cultivar susceptibility to the yellowing disease is an aspect that should be studied in more detail if breeding programs for resistance are to be initiated.

The yellowing disease of tomato represents a new threat to tomato production in southern Spain, where crops have been seriously affected in recent years by whitefly-transmitted geminiviruses such as TYLCV-Sar and TYLCV-Is (10). It is suspected that this yellowing disease was the cause of an important part of the severe yield losses that occurred in 1999. A close correlation was found in this study between the exhibition of yellowing symptoms and presence of ToCV infection. The ability of the $\mathrm{Q}$ biotype of $B$. tabaci to transmit ToCV extended the range of $B$. tabaci types able to transmit ToCV beyond biotypes A and B $(13,14)$. ToCV can also be transmitted by Trialeurodes vaporariorum Westwood (13), which exists in colder regions of Europe.

The role of other viruses in the yellowing disease epidemics in Spain, such as TICV $(13,15)$ or a new crinivirus found in tomatoes in the Canary Islands (12), remains unknown. However, this is the first report of $\mathrm{ToCV}$ causing epidemics in tomato in Europe. Yellowing symptoms similar to those described here were also observed in tomato crops in southern Portugal during 1999 that seemed also to be associated with ToCV infections (G. P. Accotto, personal communication). Two other criniviruses have been reported in recent years from southern Spain to cause serious damage in cucurbit crops, Beet pseudoyellows virus and Cucumber yellow stunting disorder virus $(1,2,9,11)$. Altogether, these data reflect the rapid emergence of whitefly-transmitted virus species of the family Closteroviridae, as has been observed in other regions of the world (13). Research efforts are urgent in order to develop effective control strategies to reduce the increasingly severe damage caused by these viruses to vegetable production in Spain.

\section{LITERATURE CITED}

1. Berdiales, B., Bernal, J. J., Sáez, E., Woudt, B., and Rodríguez-Cerezo, E. 1999. Occurrence of cucurbit yellow stunting disorder virus (CYSDV) and beet pseudo-yellows virus in cucurbit crops in Spain and transmission of CYSDV by two biotypes of Bemisia tabaci. Eur. J. Plant Pathol. 105:211-215.

2. Célix, A., López-Sesé, A., Almarza, N., Gómez-Guillamón, M. L., and RodríguezCerezo, E. 1996. Characterization of cucurbit yellow stunting disorder virus, a Bemisia tabaci-transmitted closterovirus. Phytopathology 86:1370-1376.

3. Devereux, J., Haeberli, P., and Smithies, O. 1984. A comprehensive set of sequence analysis programs for the VAX. Nucleic Acids Res. 12:387-395.

4. Duffus, J. E., Liu, H.-Y., and Wisler, C. 1996. Tomato infectious chlorosis virus-a new clostero-like virus transmitted by Trialeu- rodes vaporariorum. Eur. J. Plant Pathol. 102:219-226

5. Guirao, P., Beitia, F., and Cenis, J. L. 1997. Biotype determination of Spanish populations of Bemisia tabaci (Homoptera: Aleyrodidae). Bull. Entomol. Res. 87:587-593.

6. Navas-Castillo, J., Sánchez-Campos, S., Díaz, J. A., Sáez-Alonso, E., and Moriones, E. 1997. First report of tomato yellow leaf curl virus-Is in Spain: coexistence of two different geminiviruses in the same epidemic outbreak. Plant Dis 81:1461.

7. Navas-Castillo, J., Sánchez-Campos, S., Díaz, J. A., Sáez-Alonso, E., and Moriones, E. 1999. Tomato yellow leaf curl virus-Is causes a novel disease of common bean and severe epidemics in tomato in Spain. Plant Dis. 83:19-32.

8. Noris, E., Hidalgo, E., Accotto, G. P., and Moriones, E. 1994. High similarity among the tomato yellow leaf curl virus isolates from the West Mediterranean Basin: the nucleotide sequence of an infectious clone from Spain. Arch. Virol. 135:165-170.

9. Rubio, L. Soong, J., Kao, J., and Falk, B. W. 1999. Geographic distribution and molecular variation of isolates of three whitefly-borne closteroviruses of cucurbits: lettuce infectious yellows virus, cucurbit yellow stunting disorder virus, and beet pseudo-yellows virus. Phytopathology 89:707-711.

10. Sánchez-Campos, S., Navas-Castillo, J., Camero, R., Soria, C., Díaz, J. A., and Moriones, E. 1999. Displacement of tomato yellow leaf curl virus (TYLCV)-Sr by TYLCV-Is in tomato epidemics in Spain. Phytopathology 89:1038-1043

11. Soria, C., Sesé, A. I. L., and Gómez-Guillamón, M. L. 1991. Resistance mechanisms of Cucumis melo var. agrestis against Trialeurodes vaporariorum and their use to control a closterovirus that causes a yellowing disease of melon. Plant Pathol. 45:761-766.

12. Wisler, G. C., Duffus, J. E., and Liu, H.-Y. 1999. Expansion of tomato criniviruses to new areas. Page 70 in: Abstr. VII Int. Plant Virus Epidemiol. Symp., Almeria, Spain.

13. Wisler, G. C., Duffus, J. E., Liu, H.-Y., and Li, R. H. 1998. Ecology and epidemiology of whitefly-transmitted closteroviruses. Plant Dis. 82:270-280.

14. Wisler, G. C., Li, R. H., Liu, H.-Y., Lowry, D. S., and Duffus, J. E. 1998. Tomato chlorosis virus: A new whitefly-transmitted, phloem limited, bipartite closterovirus of tomato. Phytopathology 88:402-409.

15. Wisler, G. C., Liu, H.-Y., Klaassen, V. A., Duffus, J. E., and Falk, B. W. 1996. Tomato infectious chlorosis virus has a bipartite genome and induces phloem-limited inclusions characteristic of the closteroviruses. Phytopathology 86:622-626. 